\title{
Main Geochemical Signatures Related to Meteoritic Impacts in Terrestrial Rocks: A Review
}

\author{
María-Jesús Muñoz-Espadas ${ }^{1}$, Jesús Martínez-Frías ${ }^{2}$ and Rosario Lunar ${ }^{3}$
}

${ }^{1}$ Departamento de Geología, Museo Nacional de Ciencias Naturales, CSIC, José Gutiérrez Abascal 2, 28006 Madrid, Spain. (majem@mncn.csic.es)

${ }^{2}$ Centro de Astrobiología, CSIC-INTA, Carretera de Torrejón a Ajalvir, 28850 Torrejón de Ardoz, Madrid, Spain. (martinezfrias@mncn.csic.es)

${ }^{3}$ Departamento de Cristalografía y Mineralogía, Facultad de Ciencias Geológicas, Universidad Complutense de Madrid, Avenida Complutense s/n, 28040 Madrid, Spain. (lunar@geo.ucm.es)

Abstract. The chemical composition of impact melt rocks, breccias and ejecta layers is dominated mainly by the proportions and composition of target rocks. However, small quantities of vaporized and molten meteorite material mixed with them significantly alter the concentrations and ratios of certain elements and isotopes. The identification of this meteoritic signature is used to propose an impact formation for structures of uncertain origin, as well as a possible criterion for inferring the impactor type. The most common criteria applied to these studies are the detection of a positive siderophile element anomaly, the Re-Os isotopic system, and the $\mathrm{Mn}-\mathrm{Cr}$ isotopic system. An enrichment in $\mathrm{Cr}, \mathrm{Ni}$ and $\mathrm{Co}$, at the ppm level, and $\mathrm{Os}, \mathrm{Re}, \mathrm{Ir}, \mathrm{Ru}, \mathrm{Rh}, \mathrm{Pd}$ and $\mathrm{Au}$, at the ppb level, usually indicates the presence of a component containing high abundances of those elements. These ratios help identify the projectile as either a chondrite or an iron meteorite, but do not detect an achondritic projectile. The application of the Re-Os system method is based in the low ${ }^{187} \mathrm{Os} /{ }^{188} \mathrm{Os}$ ratio of chondritic and iron meteorites, in comparison with present day higher ratio of normal upper crust, and the high Os contents in meteorites compared to crustal rocks. The admixture of a meteoritic component to crustal rocks produces a ${ }^{187} \mathrm{Os} /{ }^{188} \mathrm{Os}$ anomaly. The $\mathrm{Mn}-\mathrm{Cr}$ system considers the deviations of the ${ }^{53} \mathrm{Cr} /{ }^{52} \mathrm{Cr}$ ratios from the standard terrestrial ${ }^{53} \mathrm{Cr} /{ }^{52} \mathrm{Cr}$ ratio as a result of the addition of an extraterrestrial component. This isotopic study often allows an accurate determination of the impactor type, especially when combined with PGE ratios. The applications and limitations of each method are reviewed. 


\section{1}

\section{Introduction}

The presence of a meteoritic component in impact-derived rocks, either in the crater or in distal ejecta, can be decisive in assigning an impact origin for a certain structure or ejecta layer (Koeberl and Shirey 1997). Some projectiles can be identified from the presence of physical remnants of the meteorite (e.g., Meteor Crater, Arizona). However, the high temperatures during impact usually vaporize impactors larger than around $40 \mathrm{~m}$ in diameter (which hardly undergo atmospheric retardation, and encounter the target with relatively undiminished force) (Grieve 1997; Montanari and Koeberl 2000). Also, meteorites are not very resistant towards erosion, and last only a few thousand years (in the case of stony meteorites) or a few tens to hundreds of thousand years (in the case of iron meteorites) on the surface of the Earth. Thus, meteorite fragments usually only survive in young $(\sim 0.1 \mathrm{Ma})$ craters smaller than $1.5 \mathrm{~km}$ in diameter. There are some rare exceptions; for example, abundant meteorite fragments have been found on the ocean floor in deposits from the Eltanin impact event, which hit the South Pacific Ocean about 2.1 million years ago (Kyte and Brownlee 1985), believed to be from a 1-4 km-sized projectile (Gersonde et al. 1997; Flores et al. 2002). Probable meteorite material (severely altered and replaced) has also been found in K-T boundary sediments (Kyte 1998; Robin et al. 1993).

A number or recent hydrocode simulations of impacts at various angles indicate that the shock pressure and the amounts of solid, molten and vaporized projectile can vary considerably with the angle of impact (e.g., Pierazzo et al. 1997; Pierazzo and Melosh 1999, 2000; Schnabel et al. 1999). A downrange focusing of projectile material was observed in oblique impacts, especially in low impact angles $\left(\leq 30^{\circ}\right)$, accompanied by the ejection of most of the projectile from the opening crater in the early stages of the impact. Shock melting and vaporization occur inside the projectile, mainly in its leading part, for all impacts except for the most oblique considered, a $15^{\circ}$ impact, decreasing with angle of impact. The shock is weakest in the trailing half of the projectile, where any component surviving the impact in the solid state has its origin. According to Pierazzo and Melosh (1999), over 50\% of the projectile is entrained in the expansion plume in the early phases of the $15^{\circ}$ impact (these authors regret that their simulations do not continue long enough to see how this early entrainment could influence the distribution of the projectile material worldwide).

Schnabel et al. 1999 considered velocity, but not angle of fall, in their simulations of an hydrocode for the Canyon Diablo impact. Their choice of a $15 \mathrm{~m}$ radius and an impact velocity of $20 \mathrm{~km} \mathrm{~s}^{-1}$ for the impactor yields an estimation of $\sim 15 \%$ solid material as a 1.5 to $2 \mathrm{~m}$ thick shell, covering the trailing hemisphere and about one third of the leading hemisphere. If an impact velocity of $15 \mathrm{~km} \mathrm{~s}^{-1}$ is assumed, the solid shell thickens to $\sim 5 \mathrm{~m}$ and constitutes $\sim 63 \%$ of the mass. In both cases the rest of the proyectile melts, but does not vaporize. Vaporization would require higher but atypical velocities for Earth-crossing asteroids. 
The quantity of the recondensed meteoritic vapor that may be mixed with the vaporized, molten, or shocked and brecciated target rocks is generally $\leq 1 \%$. Schmidt et al. (1997) determined a meteoritic component of $0.5 \%$ of a nominal CI component for Sääksjärvi crater, and about $0.1 \%$ for Mien and Dellen. French et al. (1997) detected a minor extraterrestrial component $(\leq 0.15 \%)$ in the meltbearing breccias of the Gardnos impact structure. Nevertheless, the abundance of a meteoritic component is sometimes found to be much higher than these values. The amounts found in samples from the Clearwater East impact structure, Canada, corresponds to 4 to $7 \%$ of a nominal CI component, according to Palme et al. 1979 and Schmidt 1997. Recently, McDonald (2002), after re-evaluating the existing PGE data, proposed that up to $8 \%$ ordinary (possibly type-L) chondrite component is present in the impact melt. For the Morokweng impact melt rocks, McDonald et al. (2001) calculated an ordinary chondrite component at levels of up to $7.5 \%$, in agreement with the earlier assessment by Koeberl et al. (1997). Such high abundances of meteoritic contamination may be explained by a higher impact angle, or lower impact velocity. In some cases it is possible to differentiate the chemical signature of the usually minute meteoritic contamination from the compositional signature of the normal terrestrial target rocks (Grieve 1991; Koeberl and Shirey 1997). For this purpose, detailed trace element and/or isotopic studies are necessary, as reviewed in the following chapters.

\section{2}

\section{Siderophile Trace Element Analysis}

Some siderophile and related elements are more abundant in meteorites than in terrestrial crustal rocks (Table 1). Therefore, melt rock siderophile and highly siderophile element (HSE) abundances and their interelement ratios in the impact rocks are compared to the average continental crust composition of these elements (Tables 1 and 2 ). An enrichment in $\mathrm{Cr}$, Ni and $\mathrm{Co}$, at ppm level, and $\mathrm{Os}, \mathrm{Re}, \mathrm{Ir}$, $\mathrm{Ru}, \mathrm{Rh}, \mathrm{Pd}$ and $\mathrm{Au}$, at ppb level, usually indicates the presence of either a chondritic or an iron meteoritic component. An achondritic signature is more difficult to discern, because these meteorites have significantly lower contents of the key siderophile elements (Koeberl and Shirey 1997; Schmidt 1997; Koeberl 1997, 1998; Table 1). Chondrites have high abundances of Cr (typically about $0.26 \mathrm{wt} \%$; Anders and Grevesse 1989), whereas iron meteorites have more variable $\mathrm{Cr}$ contents that are typically around 100 times lower than in chondrites (Buchwald 1975). Enrichments in $\mathrm{Cr}$ and low $\mathrm{Ni} / \mathrm{Cr}$ or $\mathrm{Co} / \mathrm{Cr}$ ratios can be used to distinguish between chondritic and iron $(\mathrm{Ni} / \mathrm{Cr} \sim 40000$ and $\mathrm{Co} / \mathrm{Cr} \sim 100$ in the latter) projectiles (Evans et al. 1993). However, as the Co, Cr, and Ni contents are common on the upper crust (average 8, 37, and 45 ppm respectively; Schmidt et al. 1997), their elemental enrichments may be ambiguous.

Platinum group elements (PGE) are better suited for identifying a meteoritic component. The abundances of the PGE ( Ru, Rh, Pd, Os, Ir, Pt) and $\mathrm{Au}$ in chondrites and iron meteorites are several orders of magnitude higher than those 
detected in terrestrial crustal rocks (e.g., Morgan et al. 1975; Palme et al. 1978, 1979; Morgan and Wandless 1983; Evans et al. 1993). Chondrites typically contain about 400-800 ppb Ir and Os (depending on the chondrite type), whereas the concentration of Ir and Os in the continental crust is approximately $0.02 \mathrm{ppb}$, according to Taylor and McLennan (1985). A more recent determination by Peucker-Ehrenbrink and Jahn (2001) sets a similar proxy for the values of Ir and Os in the upper continental crust: 22 and $31 \mathrm{pg} / \mathrm{g}$, respectively. This means that the signal to background ratio is very high for PGE in impact rocks. The abundance of platinum-group elements and their interelemental ratios have been used to determine the type or class of meteorite. However, it has to be considered that some PGE enrichment is normal in certain terrestrial rocks; for example, gold mineralizations near the Bosumtwi crater were suggested to be responsible for the Ir enrichment in Ivory Coast tektites (Jones, 1985). Although the degree of PGE fractionation in various types of mantle rocks has been recognized to be quite large (McDonald et al. 1994; Gueddari et al 1999; Rehkämper et al. 1999; Schmidt et al. 2000) the PGE patterns of the mantle and in some mantle-derived rocks may be similar to those of chondrites (Table 1; Koeberl and Shirey 1997).

Table 1. Siderophile elements composition of several terrestrial (basalt, granite, peridotite and Earth's upper crust) meteoritic (CI, eucrite), and impact (Clearwater East structure) materials.

\begin{tabular}{cccccccc}
\hline & $\begin{array}{c}\text { Basalt } \\
\text { JB-1A } \\
(1)\end{array}$ & $\begin{array}{c}\text { Granite } \\
\text { G-1 } \\
(2)\end{array}$ & $\begin{array}{c}\text { Peridotite } \\
\text { JP } \\
(1)\end{array}$ & $\begin{array}{c}\text { Upper } \\
\text { continental } \\
\text { crust } \\
(3)\end{array}$ & $\begin{array}{c}\text { CI } \\
(4)\end{array}$ & $\begin{array}{c}\text { Eucrite } \\
\text { (Juvinas) } \\
(5)\end{array}$ & $\begin{array}{c}\text { Clearwater } \\
\text { East Impact } \\
\text { melt rocks } \\
(6)\end{array}$ \\
\hline ppm & & & & & & & - \\
$\mathrm{Co}$ & 38.6 & 2.3 & 116 & $8^{\#}$ & $508^{\mathrm{a}}$ & 3.3 & - \\
$\mathrm{Cr}$ & 392 & 20 & 2807 & $37^{\#}$ & $2650^{\mathrm{a}}$ & 2330 & - \\
$\mathrm{Ni}$ & 139 & 3.4 & 2458 & $45^{\#}$ & 10700 & 1.1 & \\
& & & & & & & \\
$\mathrm{ppb}$ & & & & & & & \\
$\mathrm{Au}$ & 0.71 & 3.2 & 2300 & 0.40 & 148 & 7.1 & 4.90 \\
$\mathrm{Ir}$ & 0.023 & 2 & 20 & 0.03 & 480 & 0.028 & 25.19 \\
$\mathrm{Os}$ & 0.018 & 0.11 & 79 & 0.03 & 492 & 0.018 & 26.94 \\
$\mathrm{Pd}$ & 0.6 & 1.9 & 13 & 2.00 & $560^{\mathrm{a}}$ & 4 & 32.20 \\
$\mathrm{Pt}$ & 1.6 & 8.2 & 49 & - & 982 & - & $153^{*}$ \\
$\mathrm{Re}$ & 0.18 & 0.63 & 0.15 & 0.08 & 39 & 0.01 & 0.58 \\
$\mathrm{Rh}$ & - & $<5$ & - & 0.38 & 140 & - & 9.58 \\
$\mathrm{Ru}$ & - & $<400$ & 65 & 1.06 & 683 & - & 38.12 \\
\hline
\end{tabular}

Data sources: (1) Terashima et al. (1994). (2) Gladney et al. (1991). (3) Schmidt (1997) except \# Schmidt et al. (1997). (4) Jochum (1996), except a Wasson and Kallemeyn (1988), average. (5) Morgan et al. (1978). (6) Average of 5 samples by Schmidt (1997), except *Evans et al. (1993), one sample.

It would, therefore, be difficult to distinguish a meteoritic component if the entire target was - for example - an ophiolite mantle section. However, impact melt rocks are silica normative when a CIPW norm is calculated, because of the 
normally high volume of siliceous crustal rocks they incorporate. Mantle rocks are generally not silica saturated, and conventional geochemistry would reveal this (McDonald, personal communication, 2002).

Knowledge of the amount of siderophile elements that are provided by the basement rocks is a prerequisite for the identification of extraterrestrial material in impact melts. This indigenous component has to be subtracted from the melt content of the siderophile elements in the impact melt or breccia to obtain the net meteoritic contribution (e.g., Palme 1980). Mixing calculations can be carried out to determine the relative proportion of the various target rocks types that are known or suspected to contribute to breccias or melt rocks (e.g., French et al. 1997; Koeberl et al. 1998b), for example, rock components found included in a suevite. The harmonic least-squares (HMX) mixing calculation program (Stöckelmann and Reimold 1989) can be employed for this purpose. Unfortunately, mixing calculations are sometimes complicated by the uncertainties surrounding the exact type and composition of target rocks. Erosion or partial burial by younger rock sequences may make it difficult to confidently estimate the proportions of different target rocks, especially if they are large or more than a few million years old (McDonald, personal communication, 2001), or the indigenous PGE concentrations very low or highly variable (e.g., Schmidt and Pernicka 1994). The analytical procedure is also difficult and time consuming, and this method only gives reliable results if the target stratigraphy is simple.

Before making calculations, the average compositions are scrutinized to determine which parameters show variations between the target rock groups large enough to be useful for distinguishing the resulting mixtures. Element concentrations likely to have undergone post-impact changes, such as alkalies, are of little use in calculating target rock proportions, as they may give unreliable results. Once a model of the bulk composition of the impact rocks has been built up, the siderophile element composition of this model is compared to the siderophile element abundances observed in the impactites. Schmidt (1997) used only one analysis (a quartz monzonite from the basement) to infer the entire target suite PGE contribution to the Clearwater East impact melt rocks, which is not very representative of the target area petrology. The composition of that quartz monzonite was then subtracted from the average PGE concentrations of the melt rocks to produce a series of "net PGE ratios". Schmidt's results appeared to match corresponding ratios in CI chondrites. However, PGE-bearing particles in the Clearwater East melt are heterogeneously distributed, yielding a broad range of Ir concentration in the melt rocks (e.g., Palme et al. 1981; Evans et al. 1993). As a result, the geochemical significance of the average concentrations used by Schmidt (1997) is questionable.

The correlation method is a better alternative. PGE-Ir regressions are frequently used for this purpose (e.g., Morgan and Petrie 1979; Palme 1980; McDonald et al. 2001). Among the HSE, Ir and Os have the lowest CI-normalized abundance in crustal rocks (6.5 and $6.2 \times 10^{-5}$, respectively; Evans et al. 1993). Consequently, their contribution to a melt rock contaminated by a meteoritic component is lower that for other elements. If the meteoritic component is homogeneously distributed and indigenous Ir is negligible, then correlations and their slopes (controlled by 
the PGE/Ir ratios of the dominant PGE component) can be determined. The y-axis intercepts at Ir equals zero is used to constrain the indigenous PGE contribution (Fig. 1). The correlation method is limited by the fact that small variations in the absolute concentrations of HSE in impact melt rock samples with high concentrations of strongly siderophile elements have a large influence on the yintercept $(a t \mathrm{Ir}=0)($ Schmidt 1997). Fitting a tightly constrained regression line, through many samples of impact melt from a crater, averages out deviations for individual samples and permits extrapolation back to a y-axis intercept that is independent of assumptions over the target rock composition (McDonald et al. 2001). McDonald (2002) reviewed and re-interpreted the available PGE data from samples from the Clearwater East impact melt with this approach and concluded that the most consistent projectile was an ordinary (possibly type-L) chondrite. This agrees with Cr isotope data of Shukolyukov and Lugmair (2000b).

Table 2. Comparison of element ratios of different meteorites and impact melt rocks

\begin{tabular}{ccccccccc}
\hline \multicolumn{7}{c}{ Meteorites } & & \multicolumn{2}{c}{ Impact Melt Rocks } \\
\hline & $\mathrm{CI}$ & $\mathrm{H}$ & $\mathrm{L}$ & $\mathrm{LL}$ & IIIAB & IAB & ClearwaterEast & Morokweng \\
\hline $\mathrm{Os} / \mathrm{Ir}$ & $1.06^{\#}$ & - & - & - & - & - & 0.98 & - \\
$\mathrm{Ru} / \mathrm{Ir}$ & 1.42 & 1.42 & 1.47 & 1.49 & 1.38 & 2.04 & 1.53 & 1.50 \\
$\mathrm{Rh} / \mathrm{Ir}$ & 0.29 & 0.30 & 0.33 & 0.34 & - & - & 0.36 & 0.53 \\
$\mathrm{Pd} / \mathrm{Ir}$ & $1.21^{\#}$ & 1.11 & 1.35 & 1.64 & 0.29 & 1.01 & $1.31^{\#}$ & 1.54 \\
$\mathrm{Pt} / \mathrm{Ir}$ & 1.97 & 2.08 & 2.17 & 2.22 & 1.9 & 2.2 & $8.6^{*}$ & 2.10 \\
$\mathrm{Ni} / \mathrm{Ir}$ & $23000^{*}$ & - & - & - & 1900 & 7800 & - & 13400 \\
$\mathrm{Cr} / \mathrm{Ir}$ & $5.5^{*}$ & - & - & - & 0.02 & - & - & 8020 \\
$\mathrm{Ir} / \mathrm{Au}$ & 3.22 & 3.45 & 3.03 & 2.70 & 5.55 & 1.05 & $5.48^{\#}$ & 3.22 \\
$\mathrm{Pt} / \mathrm{Au}$ & $7.07^{*}$ & - & - & - & 10.7 & 2.3 & $2.95^{*}$ & - \\
$\mathrm{Pd} / \mathrm{Au}$ & $4.0^{*}$ & - & - & - & 6.6 & 1.2 & $1.97^{*}$ & - \\
$\mathrm{Ru} / \mathrm{Rh}$ & 4.95 & 4.63 & 4.40 & 4.33 & - & - & 3.04 & 4.14 \\
$\mathrm{Ir} / \mathrm{Re}$ & $12^{\#}$ & - & - & - & - & - & $57^{\#}$ & - \\
$\mathrm{Pt} / \mathrm{Pd}$ & - & 1.88 & 1.16 & 1.35 & - & - & - & 1.29 \\
$\mathrm{Pt} / \mathrm{Ru}$ & $1.39^{*}$ & - & - & - & 1.4 & 1.1 & $8.6^{*}$ & - \\
$\mathrm{Pd} / \mathrm{Ru}$ & $0.79^{*}$ & - & - & - & 0.12 & 3.55 & $2.95^{*}$ & 1.09 \\
\hline $\mathrm{D}$ & & - & - & - & & - & - & \\
\hline
\end{tabular}

Data sources: Averages: CI: Jochum (1996), 2 analyses, except ${ }^{\#}$ Schmidt (1997) and *Evans et al. (1993) and references therein. H, L and LL: McDonald (2002) Number of analyses: H, 2; L, 3; LL, 2. IIIAB and IAB: Evans et al. (1993) and references therein. Clearwater East: Impact melt rocks, McDonald (2002), except " Schmidt (1997), 5 analyses, and *Evans et al. (1993), 2 analyses. Morokweng: Impact melt rocks, McDonald et al. (2001), 16-18 analyses, depending on ratio.

Different processes occurring during the formation of impact glasses and melts cause problems with meteoritic component identification. The main factors controlling the incorporation of a meteoritic component into impact rocks are impact angle and projectile velocity (see introduction). However, this energy 
scaling relationship does not explain the fractionation detected within a single crater (e.g., Meteor Crater, Wabar, and some Australian craters). Locations at different radial distances from the impact site have been found to show different siderophile element and PGE signatures, which do not coincide exactly with the interelement ratios of the impactor when it is partly preserved. Differences in vaporization and/or condensation temperatures could cause the PGE to fractionate among themselves, but no obvious correlation with any physical or chemical properties has jet been detected (Attrep et al. 1991; Mittlefehldt et al. 1992 a, b; Koeberl and Shirey 1997). Fractionation effects have also been detected for distal ejecta from the K-T boundary impact in different localities (Evans et al. 1993; Evans and Chai 1997).

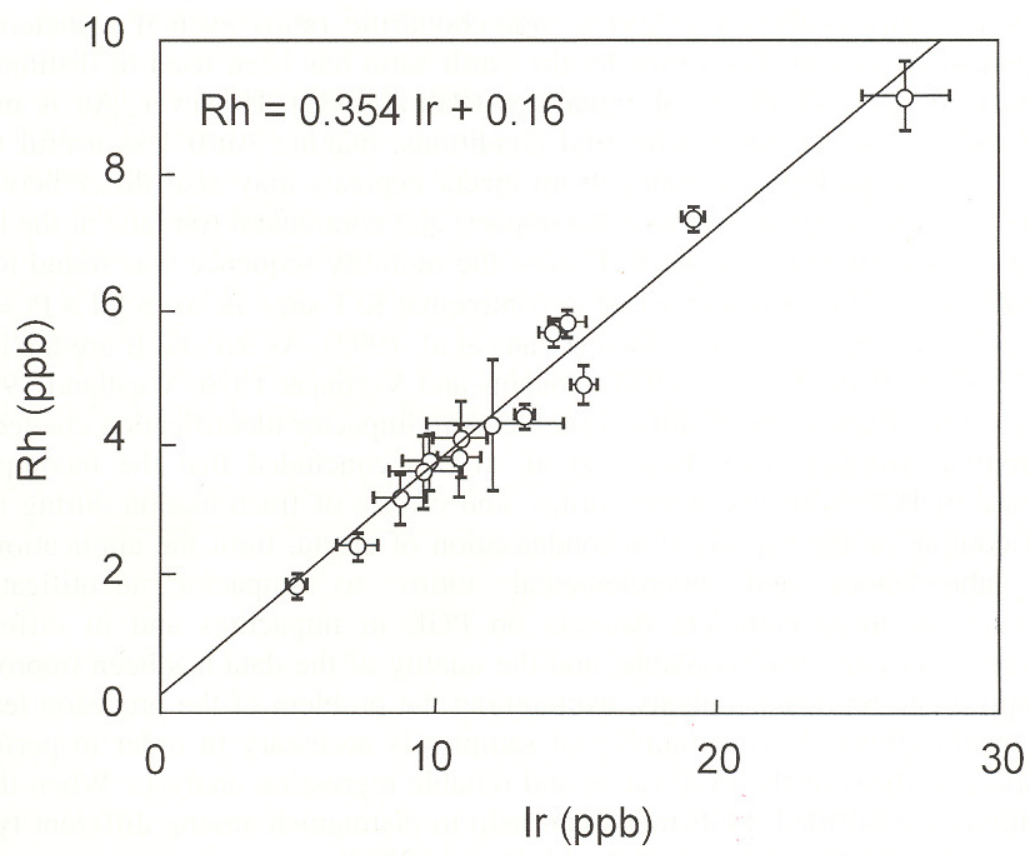

Fig. 1. Regression between contents of Ir and Rh in impact melt rocks from the Morokweng structure, South Africa. Error bars show one standard deviation of the mean concentration. From McDonald et al. (2001).

Siderophile element fractionation in the impact melt while still molten is also possible. In large craters, where the melt can remain hot for several thousand years, different mineral phases, such as pyroxenes, magnetite and chromite, may take up various proportions of the siderophile elements $(\mathrm{Ni}, \mathrm{Co}$, and $\mathrm{Cr}$, but not PGE), leading to an irregular distribution of these elements and, possibly, fractionated interelement ratios and patterns (Palme et al. 1979; Koeberl et al. 1994a, Koeberl 1998). This can render ratios such as $\mathrm{Cr} / \mathrm{Ni}, \mathrm{Ni} / \mathrm{Ir}$ and $\mathrm{Cr} / \mathrm{Ir}$ of 
limited use. The fractionation of PGE observed in Clearwater East and Morokweng was attributed to a small-scale redistribution in sulphide and oxide phases (e.g., magnetite, chromite; Koeberl 1997). However, other authors (McDonald, personal communication, 2001) consider that the evidence for vaporization or condensation fractionation of the PGEs in thick melt sheets or global ejecta is not strong, and possibly explained by the small sizes of the sample taken for analysis. When larger samples are considered, the PGEs appear less fractionated.

Hydrothermal processes associated with the hot impact melt may also change the PGE concentrations in impact rocks (Gostin et al. 1989; Wallace et al. 1990), although distant ejecta deposits are not affected by this process. The relative mobility of these elements has to be considered before interpreting the ratios involving PGE, as this may lead to non-chondritic ratios even if a meteoritic component is present. For example, the $\mathrm{Au} / \mathrm{Ir}$ ratio has been used to distinguish between cosmic and terrestrial signatures (Palme 1982). However, Au is much more mobile than Ir under terrestrial conditions, making Au/Ir less useful than other PGE ratios. Remobilization from ejecta deposits may also differ between marine (underwater at the time of the impact) and continental (on land at the time of the impact) sites. In marine K-T sites, the mobility sequence was found to be $\mathrm{Rh}>\mathrm{Au}>\mathrm{Pd}>\mathrm{Pt}>\mathrm{Ru}>\mathrm{Ir}$, while in continental $\mathrm{K}$ - $\mathrm{T}$ sites an $\mathrm{Au}>\mathrm{Pd}>\mathrm{Pt} \approx \mathrm{Rh}$ $>\mathrm{Ru}>\mathrm{Ir}$ sequence was determined (Evans et al. 1993). As Ru and Ir are the least mobile of the PGE (Cousins 1973; Cousins and Vermaak 1976; Westland 1981), the use of the $\mathrm{Ru} / \mathrm{Ir}$ ratio minimizes problems in impactor identification created by differential remobilization. Evans et al. (1993) concluded that the incomplete database of PGE contents in meteorites, and effects of fractionation during melt sheet cooling or the vaporization/condensation of ejecta, limit the application of PGE abundances and interelemental ratios to impactor identification. Nevertheless, more complete datasets on PGE in impactites and in different meteorite types are now available, and the quality of the data has been improved by appropriate replicate analysis, overcoming the problem of the precision levels (McDonald 1998). A large number of samples is necessary in order to perform statistical analysis of the PGE ratios and reliable regression analysis. When these conditions are fulfilled, PGE ratios can help to distinguish among different types of projectiles (McDonald et al. 2001; McDonald 2002).

\section{3}

\section{The Re-Os Isotopic System}

The abundance of Re and Os and the ${ }^{188} \mathrm{Os} /{ }^{187} \mathrm{Os}$ isotopic ratios may allow a confirmation of the presence of a cosmic component in terrestrial rocks, although they do not permit the determination of the meteorite type. This was first shown for the K-T boundary by Turekian (1982) and Luck and Turekian (1983), and for rocks at impact craters by Fehn et al. (1986). The Re-Os isotopic system is based on the ${ }^{187} \mathrm{Re}$ decay via $\beta$-decay into ${ }^{187} \mathrm{Os}$, with a halflife of $42.3 \pm 1.3 \mathrm{Ga}$ (Lindner 
et al. 1989). All seven naturally occurring osmium isotopes are stable. Regarding the geochemical behavior of Re and Os, the former is moderately incompatible and is, therefore, enriched in the melt, whereas the latter is strongly retained in the mantle during partial melting of mantle rocks and remains in the residue. This behavior results in high Re, but low Os, concentrations in most crustal rocks, and their Re/Os ratio is usually no less than 10 (Koeberl 1998). The Earth's mantle has Re and Os concentrations, which are much lower than those of meteorites. However its Re/Os ratio is indistinguishable from that of meteorites (Faure 1986), especially chondrites and irons, which have relatively high Re and Os contents, with Os more abundant than Re (ca. 600 and 50 ppb, respectively, in chondrites), resulting in $\mathrm{Re} / \mathrm{Os}$ ratios $\leq 0.1$. Moreover, achondrites are an exception, as they have low Re and Os concentrations (contents of 0.06 and $0.44 \mathrm{ppb}$, respectively, have been measured in Moore County eucrite; Mason 1979; Table 3). Consequently, meteoritic and mantle rock ${ }^{187} \mathrm{Os} /{ }^{188} \mathrm{Os}$ ratios experience only small changes with time, in contrast to crustal rocks (Fig. 2). Present-day mantle has a low ${ }^{187}$ Os $/{ }^{188}$ Os ratio of 0.12-0.13 (e.g., Smoliar et al. 1996, Meisel et al. 1996). Meteorites also have low ${ }^{187} \mathrm{Os} /{ }^{188} \mathrm{Os}$ ratios. For example, a suite of data for 12 ordinary chondrites define a narrow range of present day ${ }^{187} \mathrm{Os} /{ }^{186} \mathrm{Os}$ of $0.1289 \pm$ 0.0011. Data for 10 enstatite chondrites define a similar average - present day ${ }^{187} \mathrm{Os} /{ }^{186} \mathrm{Os}$ of $0.1283 \pm 0.0005$. In contrast, a suite of four carbonaceous chondrites define a $1-2 \%$ lower ${ }^{187} \mathrm{Os} /{ }^{186} \mathrm{Os}$ of $0.1259 \pm 0.0005$ (Meisel et al. 1996). ${ }^{187} \mathrm{Os} /{ }^{188}$ Os ratios of about $0.67-1.61$ are representative of upper continental crust (Koeberl and Shirey 1997; Koeberl et al. 1998a).

Table 3. Average abundances of Re and Os in terrestrial and extraterrestrial materials.

\begin{tabular}{lccc}
\hline Rock & Re (ppb) & Os (ppb) & Re/Os \\
\hline CI chondrites (1) & 36.5 & 486 & 0.075 \\
Ordinary chondrites (1) & 57 & 660 & 0.086 \\
IIAB (1) & $1.39-4799$ & $12.7-65270$ & $0.073-0.11$ \\
IIIAB (1) & $2.83-1444$ & $17.1-18430$ & $0.078-0.202$ \\
Eucrites (1) & $0.01-0.06$ & $0.018-0.44$ & $0.081-0.136$ \\
Basalt JB-1A (2) & 0.18 & 0.018 & 10 \\
Granite G-1 (3) & 0.63 & 0.11 & 5.727 \\
Peridotite JP (2) & 0.15 & 79 & 0.002 \\
Average Upper Continental Crust (4) & 0.8 & 0.03 & 2.66 \\
Average Upper Continental Crust (5) & 0.198 & 0.031 & 6.387 \\
\hline
\end{tabular}

Data sources: (1) Koeberl and Shirey (1997) and references therein; (2) Terashima et al. (1994); (3) Gladney et al. (1991); (4) Schmidt (1997); (5) Peucker-Ehrenbrink and Jahn (2001).

Due to the high Os and Re abundances in chondrites, the admixture of a small meteoritic component to crustal target material significantly alters the Os isotopic 
characteristics of the resulting impact melt or breccias (Table 4, Fig. 3). While a high abundance of Os could be due to crustal enrichment processes and incorporation of ore minerals, non-crustal Os isotopic compositions clearly indicate the presence of a meteoritic or mantle component. To distinguish between mantle and meteoritic signals, the differences in total abundance of Os in both materials is considered (Koeberl and Shirey 1997).

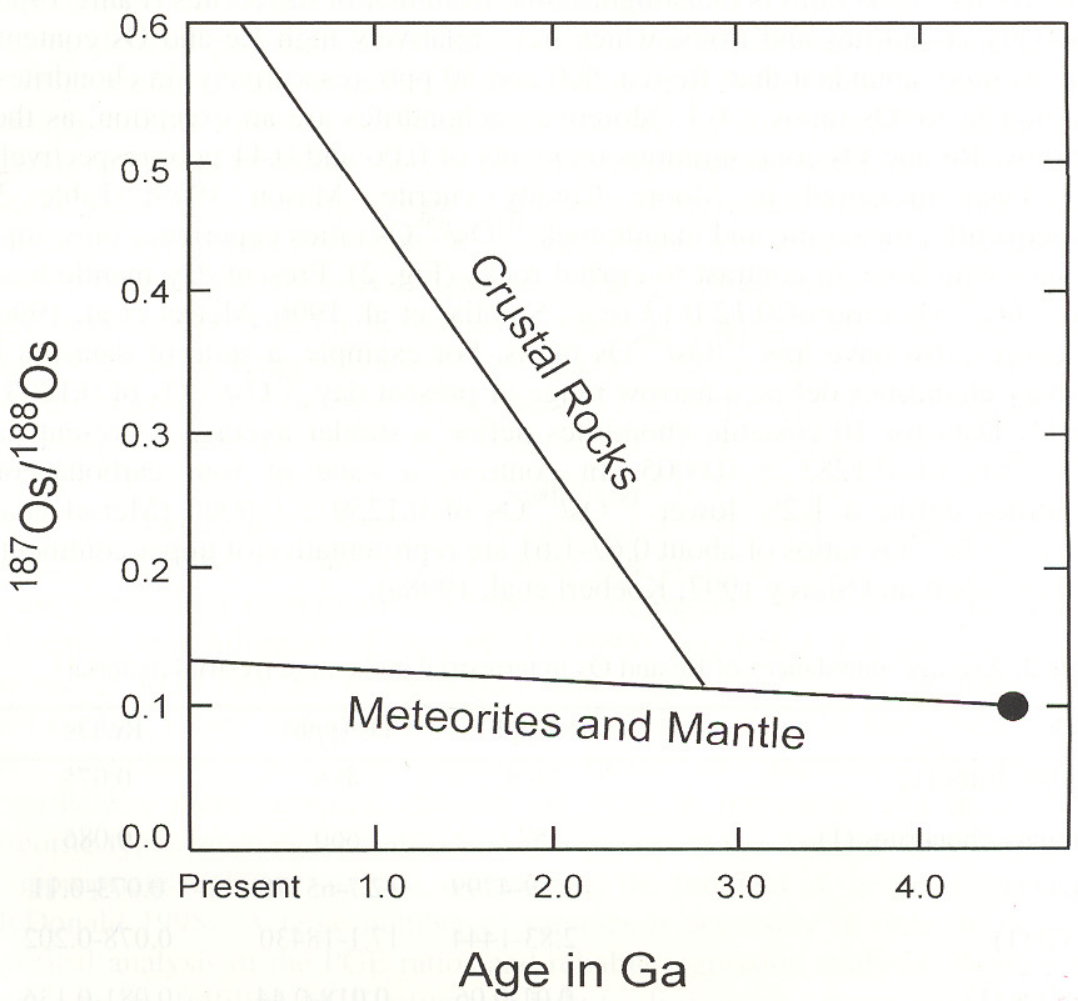

Fig. 2. Schematic evolution of the ${ }^{187} \mathrm{Os} /{ }^{188} \mathrm{Os}$ ratio of meteorites and the Earth's mantle and crust. From Faure (1986).

Mantle rocks have about 1-4 ppb Os, and typical chondrites have about 400800 ppb Os. Thus, about 100 times more mantle material than meteoritic material would need to be added to normal crustal rocks to give the same Os isotopic ratio as the bulk rock. Ultramafic precursor rocks may be discerned by detailed geological field investigation, petrographic study of the rocks, trace element and, if necessary, supplementary $\mathrm{Rb}-\mathrm{Sr}$ and/or Sm-Nd isotopic analysis (Koeberl and Shirey 1997).

The method has been applied to the K-T boundary clay in various locations, in order to test its impact versus volcanic origin, e.g., Stevns Klint, Denmark (Luck 
and Turekian, 1983), Woodside Creek, New Zealand (Lichte et al. 1986), and Sumbar, Turkmenistan (Meisel et al. 1995). In the latter study, the variation of the ${ }^{187} \mathrm{Os} /{ }^{188}$ Os ratio was measured across a complete boundary section. A significant sudden decrease of the ${ }^{187} \mathrm{Os} /{ }^{188} \mathrm{Os}$ ratio from the end-Cretaceous rock layers to the actual K-T boundary clay was observed, in correlation with the maximum Ir and Os concentration; in the early Tertiary rocks, the ${ }^{187} \mathrm{Os} /{ }^{188} \mathrm{Os}$ ratio increases to higher values. The osmium isotopic system has also proved useful to confirm the impact origin of suspicious structures. The origin of Vredefort structure in South Africa, for example, has been controversial. Granophyric rock dykes exposed in its basement and along the boundary between the core and the supracrustal rocks have been suggested to represent either an igneous intrusion (e.g., Bisschoff 1972), or impact melt injected into fractures in the floor of the impact structure (French et al. 1989; French and Nielsen 1990). Koeberl et al. (1996a) found that most Vredefort Granophyre samples have considerably higher Os contents than the country rocks from which the granophyre is likely to have been formed. The ${ }^{187} \mathrm{Os} /{ }^{188} \mathrm{Os}$ ratios overlap the meteoritic data range and indicate that the granophyre samples contain some meteoritic Os, suggesting up to $0.2 \%$ of a chondritic component. The Vredefort Granophyre was, therefore, confirmed to represent an impact melt rock. Other case studies are the Ivory Coast tektites and

Table 4. Os abundances and isotopic data for K-T boundary samples, and a variety of impact glasses and impact breccias (Koeberl and Shirey 1997, and references therein).

\begin{tabular}{lccc}
\hline \multicolumn{1}{c}{ Sample } & Os $(\mathrm{ppb})$ & ${ }^{187} \mathrm{Os} /{ }^{188} \mathrm{Os}$ & ${ }^{187} \mathrm{Os} /{ }^{186} \mathrm{Os}$ \\
\hline K-T boundary localities & & & \\
Starkville South, CO, U.S.A. & 25 & 0.14 & 1.2 \\
Madrid, CO, U.S.A. & 12.2 & 0.140 & 1.167 \\
Woodside Creek, New Zealand & 60 & 0.135 & 1.12 \\
Stevns Klint, Denmark & 110 & 0.1668 & 1.386 \\
Ivory Coast tektites & & & \\
IVC 8902 & 0.0889 & 0.2087 & 1.734 \\
IVC 2069 & 0.129 & 0.1528 & 1.270 \\
Bosumtwi crater impact glasses & & & \\
BI 9201 & 0.125 & 0.9009 & 7.49 \\
Kalkkop crater impact breccias & & & \\
Br-2 (100.4) & 0.0354 & 0.487 & 4.049 \\
Br-3 (112.7) & 0.1886 & 0.2149 & 1.790 \\
Chicxulub impact melt rocks & & & \\
CI-N10-1A & 25.2 & 0.113 & 0.941 \\
CI-N10-2 & 0.056 & 0.505 & 4.200 \\
\hline
\end{tabular}


Morokweng crater (Koeberl and Shirey 1993a, b; Koeberl et al. 2002), Chicxulub, Mexico (Koeberl et al. 1994a), Saltpan crater, South Africa (Koeberl et al. 1994b), Kalkkop crater, South Africa (Koeberl et al. 1994c), or the Manson structure, Iowa, U.S.A. (Koeberl and Shirey 1996; Koeberl et al. 1996b).

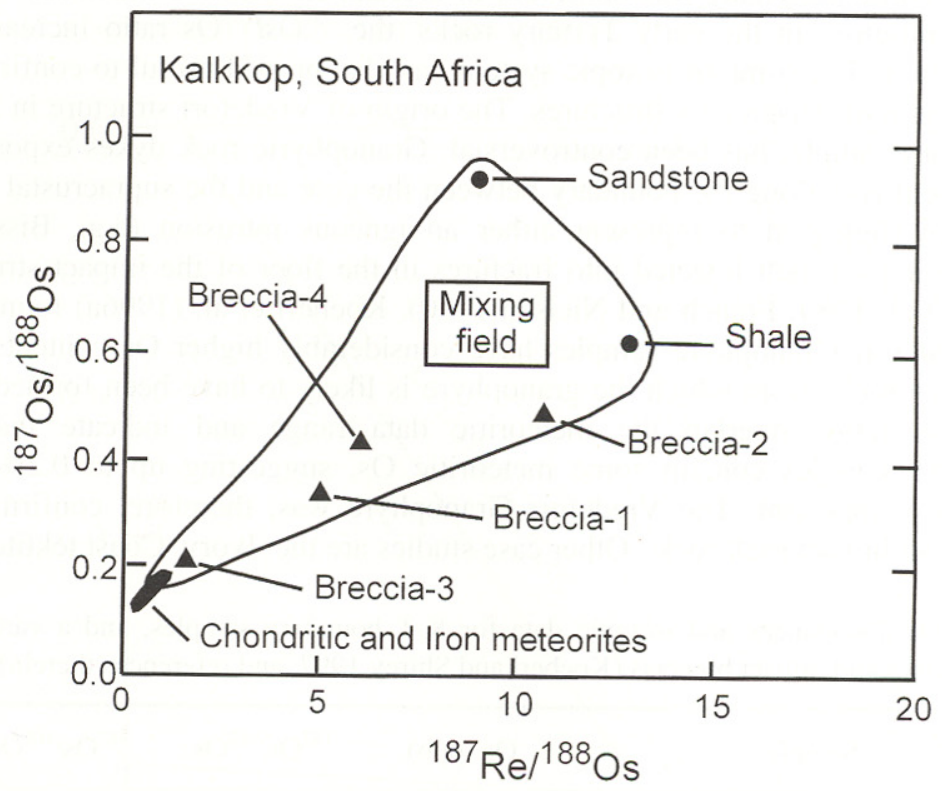

Fig. 3. Ratios of ${ }^{187} \mathrm{Os} /{ }^{188}$ Os versus ${ }^{187} \mathrm{Re} /{ }^{188}$ Os for target rocks (shale and sandstone) of the Kalkkop impact crater, South Africa, in comparison with data for four impact breccias and the data array for chondritic and iron meteorites (small solid dots). From Koeberl and Shirey (1997).

\section{4}

\section{The Cr-Mn Isotopic System}

The chromium isotope systematics were recently explored for impact studies. The radioactive nuclide ${ }^{53} \mathrm{Mn}$ decays to stable ${ }^{53} \mathrm{Cr}$ with a half-life of $3.7 \mathrm{Ma} .53 \mathrm{Mn}$ is now extinct in the Solar System, but was present when the early planetesimals were forming, as indicated by variations in the relative abundance of the radiogenic daughter ${ }^{53} \mathrm{Cr}$ in various ancient objects in the Solar System (Birck and Allègre 1988; Hutcheon et al. 1992; Nyquist et al. 1997). Lugmair and Shukolyukov (1998) performed high-precision mass spectrometric analysis of chromium, and developed a technique that allows to measure small ${ }^{53} \mathrm{Cr} /{ }^{52} \mathrm{Cr}$ variations of less than $1 \varepsilon$ with an uncertainty of 0.05 to $0.10 \varepsilon$ units $(1 \varepsilon$ is one part in $\left.10^{4}\right)$. These isotopic variations are measured as the deviations of the 
${ }^{53} \mathrm{Cr} /{ }^{52} \mathrm{Cr}$ ratios from the standard terrestrial ${ }^{53} \mathrm{Cr} /{ }^{52} \mathrm{Cr}$ ratio. Terrestrial samples exhibit ${ }^{53} \mathrm{Cr} /{ }^{52} \mathrm{Cr} \sim 0 \varepsilon$ regardless of their origin, because the Earth homogenized after ${ }^{53} \mathrm{Mn}$ had fully decayed (Table 5). Samples from the Moon give the same result as the Earth, because of their close genetic relationship (e.g., Hartmann and Davis 1975; Hartmann 1986; Stevenson 1987; Melosh 1989). Most classes of meteorite have excess ${ }^{53} \mathrm{Cr}$ relative to the terrestrial value. The ordinary chondrites show a characteristic ${ }^{53} \mathrm{Cr} /{ }^{52} \mathrm{Cr}$ of $\sim 0.48$ \&. Although the ${ }^{53} \mathrm{Cr} /{ }^{52} \mathrm{Cr}$ ratios of individual eucrites and diogenites vary because of an early planet-wide $\mathrm{Mn} / \mathrm{Cr}$ fractionation, their parent body (Vesta) is characterized by the close-to-chondritic ${ }^{53} \mathrm{Cr}$ excess of $\sim 0.57 \varepsilon$. The $\mathrm{Mn}-\mathrm{Cr}$ isotope systematics of the angrites, primitive achondrites, and pallasites are also consistent with ${ }^{53} \mathrm{Cr} /{ }^{52} \mathrm{Cr}$ ratios of $\sim 0.5 \varepsilon$ in their bulk parent bodies. The ${ }^{53} \mathrm{Cr}$ excess is $\sim 0.22 \varepsilon$ for the Martian meteorites, and $\sim 0.17 \&$ for the EH-chondrites (Fig. 4; Shukolyukov and Lugmair 1998). Carbonaceous chondrites, however, show an apparent deficit of ${ }^{53} \mathrm{Cr}$ of $\sim-0.40 \varepsilon$. This results from the use of ${ }^{54} \mathrm{Cr} /{ }^{52} \mathrm{Cr}$ ratio for a second order fractionation correction. They were found to contain $\mathrm{Cr}$ of presolar origin, characterized by mostly elevated but sometimes lower than normal ${ }^{54} \mathrm{Cr} /{ }^{52} \mathrm{Cr}$ ratios (Podosek et al. 1997). The actual, unnormalized ${ }^{53} \mathrm{Cr} /{ }^{52} \mathrm{Cr}$ ratio is similar to that of other undifferentiated meteorites, and the apparent ${ }^{53} \mathrm{Cr}$ deficit in the carbonaceous chondrites is actually due to an excess of ${ }^{54} \mathrm{Cr}$.

Since the measured excesses of radiogenic ${ }^{53} \mathrm{Cr}$ are very small for the samples with relatively low $\mathrm{Cr}$ concentrations, such as olivines and those with long exposure ages, a potential contribution from spallation reactions has to be taken into account. The use of the ${ }^{54} \mathrm{Cr} /{ }^{52} \mathrm{Cr}$ ratio for a second order fractionation correction introduces an additional uncertainty due to the presence of spallogenic ${ }^{54} \mathrm{Cr}$. Birck and Allègre (1985) determined production rates for $\mathrm{Cr}$ in the iron meteorite Grant. The production rates for ${ }^{53} \mathrm{Cr}$ and ${ }^{54} \mathrm{Cr}$ turned out to be approximately the same: $\sim 2.9 \times 10^{11}$ atoms/g per Ma. These values agree reasonably well with the less precise values for the production rate of ${ }^{53} \mathrm{Cr}$ in Grant of $\sim 2.3 \times 10^{11}$ atoms/g per Ma by Shima and Honda (1966). Thus, with known exposure age and $\mathrm{Cr}$ and $\mathrm{Fe}$ concentrations ( $\mathrm{Fe}$ is the main target for $\mathrm{Cr}$ production), a spallation correction can be performed (Lugmair and Shukolyukov 1998).

The observed distribution of radiogenic ${ }^{53} \mathrm{Cr}$ may not be due to differences in the bulk $\mathrm{Mn} / \mathrm{Cr}$ ratios of the parent bodies. Instead, this distribution may reflect an original spatial heterogeneity of ${ }^{53} \mathrm{Mn}$ in the early Solar System, which is now evident as a radial gradient in the radiogenic ${ }^{53} \mathrm{Cr}$ abundances (Lugmair and Shukolyukov 1998; Shukolyukov and Lugmair 2000a). Regardless of the scenario, this observed difference allows us to distinguish extraterrestrial material on the basis of high-precision measurements of the Cr isotopic composition.

This method was successfully applied by Shukolyukov et al. (1999) and Koeberl et al. (2002) for the Morokweng structure impact melt. A substantial portion of the $\mathrm{Cr}$ in their samples was found to be of cosmic origin $\left({ }^{53} \mathrm{Cr} /{ }^{52} \mathrm{Cr}=\right.$ 0.24-0.27 ع), and the isotopic ratio was clearly different from those of the carbonaceous and enstatitic chondrites. Thus, they concluded that the most probable projectile is an ordinary chondrite type material. The authors 
Table 5. ${ }^{53} \mathrm{Cr} /{ }^{52} \mathrm{Cr}$ ratios and $\mathrm{Cr}$ concentrations in terrestrial and extraterrestrial samples (from Shukolyukov and Lugmair 1998).

\begin{tabular}{|c|c|c|}
\hline Sample & $\mathrm{Cr}(\mathrm{ppm})$ & ${ }^{53} \mathrm{Cr} /{ }^{52} \mathrm{Cr}\left(\varepsilon^{*}\right)$ \\
\hline & $\begin{array}{l}\text { Terrestrial minerals, rock, } \\
\text { and sediment }\end{array}$ & \\
\hline Laboratory standard - terrestrial normal & - & $\equiv 0$ \\
\hline KH-1 Px, Kilbourne Hole, USA (px) & 2500 & $-0.01 \pm 0.08$ \\
\hline JAG 89-9, Jagersfontein, S. Africa (gte) & - & $0.04 \pm 0.08$ \\
\hline $\begin{array}{l}\text { SC Ol, San Carlos Volcanic Field, USA } \\
\text { (ol) }\end{array}$ & 202 & $-0.03 \pm 0.11$ \\
\hline MB 81-14, Deccan Traps, India (basalt) & 112 & $-0.04 \pm 0.06$ \\
\hline \multirow[t]{2}{*}{ ODP 31-302-5-5, Western Pacific (clay) } & 34 & $-0.02 \pm 0.09$ \\
\hline & $\begin{array}{l}\text { Bulk meteorites and their } \\
\text { parent bodies }\end{array}$ & \\
\hline Allende (CV3) & 3540 & $-0.38 \pm 0.11$ \\
\hline Orgueil (CI) & 2530 & $-0.46 \pm 0.07$ \\
\hline $\mathrm{OC}(\mathrm{H}, \mathrm{L})$ and their parent bodies & $\sim 3900$ & $\sim 0.48$ \\
\hline Eucrites & $1600-3200$ & $0.7-1.3$ \\
\hline Diogenites & $6000-12700$ & $0.4-0.6$ \\
\hline HED parent body (Vesta) & - & $\sim 0.57 \dagger$ \\
\hline $\begin{array}{l}\text { Primitive achondrites and their parent } \\
\text { bodies }\end{array}$ & - & $\sim 0.53$ \\
\hline Angrites & $800-1800$ & $0.4-0.7$ \\
\hline Angrite parent body & - & $\sim 0.48 \dagger$ \\
\hline Pallasite parent body & - & $\sim 0.52 \dagger$ \\
\hline SNC-meteorites (Mars) & - & $\sim 0.22$ \\
\hline $\mathrm{EC}(\mathrm{EH})$ and their parent body & $2900-3900$ & $\sim 0.17$ \\
\hline Lunar anorthosite 60025 & 24 & $0.00 \pm 0.09$ \\
\hline
\end{tabular}

*1 $1 \varepsilon$ unit is 1 part in $10^{4} . \dagger$ Calculation based on $\mathrm{Mn}-\mathrm{Cr}$ isotope systematics. px $=$ pyroxene, gte $=$ garnet, ol $=$ olivine .

complemented the Cr isotope study with the PGE ratios ( $\mathrm{Cr} / \mathrm{Ir})$ to focus their result to a L chondrite. Shukolyukov and Lugmair (1998) measured chromium concentrations in K-T boundary sediments commonly 20 to 30 times higher than those in background sediments (e.g., Kyte et al. 1980, 1985). In samples from Caravaca, Spain, Shukolyukov and Lugmair (1998) measured $\mathrm{Cr}$ isotopic 
characteristics of the K-T boundary clays, finding contents of $991 \mathrm{ppm} \mathrm{Cr}$, in comparison with 40 and 69 ppm measured below and above the impact layer (Table 6), and the 185 ppm of the average $\mathrm{Cr}$ concentration of the bulk continental crust (Taylor and McLennan 1985). The $\mathrm{Cr}$ isotopic system can then be used to test if a considerable part of the $\mathrm{Cr}$ in a supposed impact layer is indeed of cosmic origin (rather than mostly from terrestrial ejecta material or volcanic ash), and it can provide direct isotopic evidence for the impact hypothesis, and in particular the impactor type. However, Shukolyukov and Lugmair (1998) noted that none of the meteorite classes they studied have a $\mathrm{Cr}$ isotopic composition similar to that of the K-T samples (which have a deficit of ${ }^{53} \mathrm{Cr}$ ). Furthermore, they tentatively indicated that the obtained deficit of ${ }^{53} \mathrm{Cr}$ could be the result of an elevated ${ }^{54} \mathrm{Cr} /{ }^{52} \mathrm{Cr}$ ratio in the samples (as discussed in the first paragraph of this section). In consequence, a carbonaceous chondrite was considered to be the best candidate for the impactor type. Their calculations showed $80 \%$ of the $\mathrm{Cr}$ in the $\mathrm{K} / \mathrm{T}$ sediments could have originated from a meteorite of this class.

Table 6. ${ }^{53} \mathrm{Cr} /{ }^{52} \mathrm{Cr}$ ratios and $\mathrm{Cr}$ concentrations in the $\mathrm{K}$ - T boundary samples and their backgrounds, and impact rocks.

\begin{tabular}{lcc}
\multicolumn{1}{c}{ Sample } & $\mathrm{Cr}(\mathrm{ppm})$ & ${ }^{53} \mathrm{Cr} /{ }^{52} \mathrm{Cr}\left(\varepsilon^{*}\right)$ \\
\hline K-T boundary and background clays (1) & 991 & $-0.40 \pm 0.08$ \\
SK503, Caravaca, Spain & 40 & $-0.01 \pm 0.07$ \\
CA10b, Caravaca, Spain, 10-15 cm below K-T (clay) & 69 & $-0.02 \pm 0.12$ \\
CA16a, Caravaca, Spain, 16-20 cm above K-T (clay) & - & $-0.32 \pm 0.06$ \\
Barberton impact deposits and background material (2) & - & $0.01 \pm 0.06$ \\
$\begin{array}{l}\text { D-4, Barberton spherule bed, South Africa } \\
\text { Background sample, 3 m below }\end{array}$ & & \\
Morokweng impact melt (3) & 359 & $0.24 \pm 0.04$ \\
MO15, Morokweng, South Africa & 408 & $0.27 \pm 0.03$ \\
MO48, Morokweng, South Africa & &
\end{tabular}

Data sources: (1) Shukolyukov and Lugmair (1998). (2) Shukolyukov and Lugmair

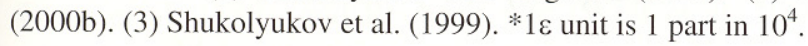

Chromium isotopic studies were necessary to confirm the presence of an extraterrestrial component in the spherule bed (S4) from the Barberton Greenstone Belt, South Africa, supporting the hypothesis of an impact origin, and making this the oldest impact deposit on Earth (Shukolyukov et al. 2000). Previous PGE analyses showing relative abundances of $\mathrm{Ir}$, Pt, and Os nearly similar to those in chondritic meteorites (Kyte et al. 1992) were not considered conclusive by some 


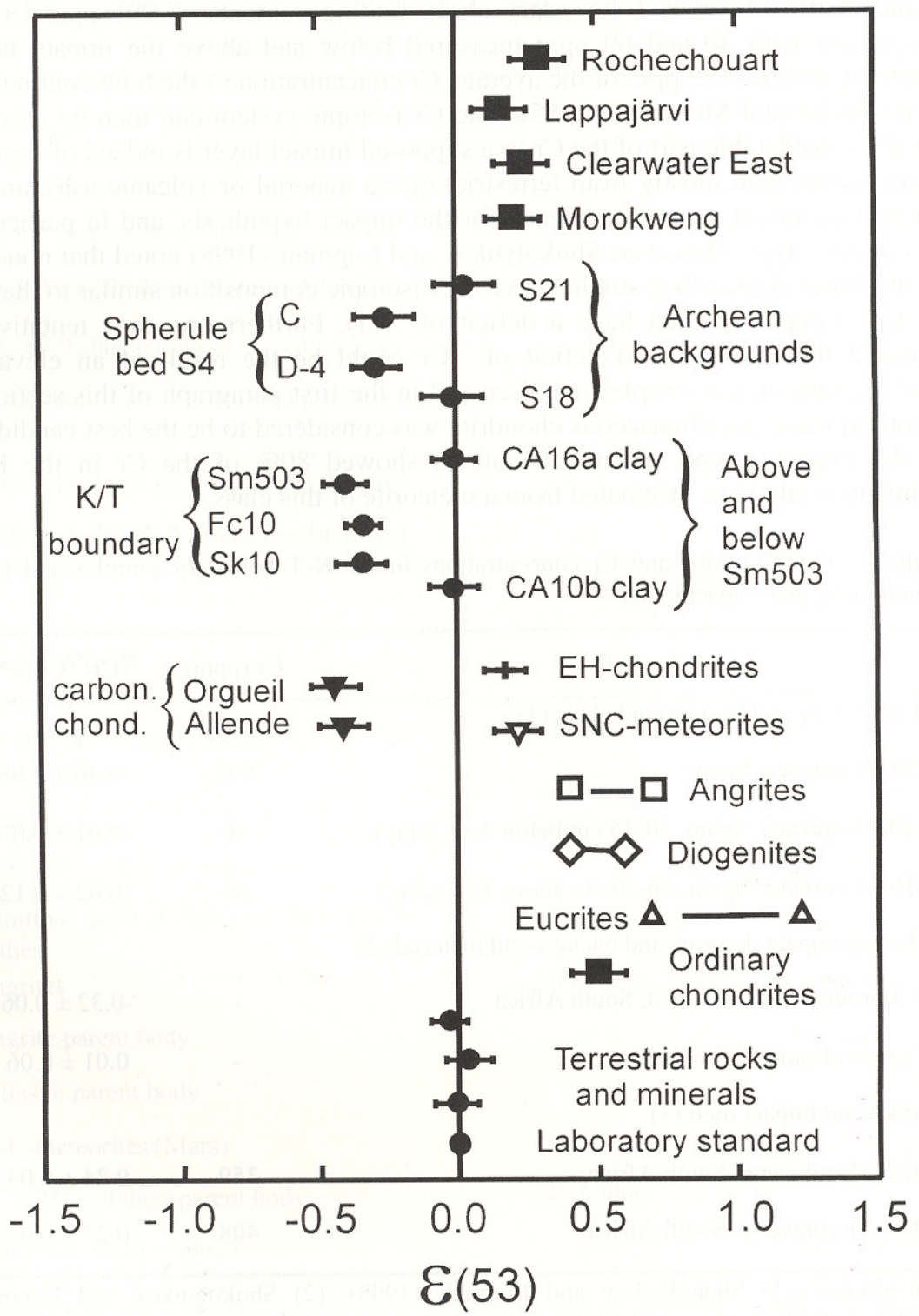

Fig. 4. ${ }^{53} \mathrm{Cr} /{ }^{52} \mathrm{Cr}$ ratios in various terrestrial, impactite, K-T boundary and meteoritic samples. After Shukolyukov and Lugmair (2000b) and Shukolyukov et al. (2000). K-T boundary samples: SM503: Caravaca, Spain; FC10 and SK10: Stevens Klint, Denmark. Archean samples: Spherule bed S4: Barberton Greenstone Belt, South Africa. 
authors (Koeberl et al. 1993; Koeberl and Reimold 1995), who argued that the extreme enrichments of siderophile elements (up to 5 times the chondritic abundances), much higher than in any other known impact deposit (or even in meteorites), could be explained by secondary mineralization. However, samples from the spherule bed were found to have a ${ }^{53} \mathrm{Cr} /{ }^{54} \mathrm{Cr}$ ratio between $\sim 0.26 \pm 0.11 \varepsilon$. and $\sim 0.32 \pm 0.06 \varepsilon$, where as background sediments yielded normal terrestrial ${ }^{53} \mathrm{Cr} /{ }^{54} \mathrm{Cr}$ ratio (Shukolyukov et al. 2000).

A drawback with the chromium isotopic method is that a substantial amount of the chromium has to be of extraterrestrial origin to show an effect in the $\mathrm{Cr}$ isotopic composition of terrestrial rocks. For example, in rocks with crustal $\mathrm{Cr}$ abundances, only meteoritic components $<1.2 \%$ can be detected (Koeberl et al. 2002). Therefore, the $\mathrm{Cr}$ isotopic method is much less sensitive than the Os isotopic method. Additionally, analytical procedure is complicated and requires extreme precision, thus limiting the number of samples that can be analyzed. Nevertheless, the $\mathrm{Cr}$ isotopic method, where applicable, can provide additional information regarding the nature of the impactor (Koeberl et al. 2002). Although this determination is not possible for iron meteorites, which do not carry significant amounts of $\mathrm{Cr}$, it allows to discern different types of ordinary chondrites, and it is the only procedure that can discriminate achondritic impactors, which have low concentrations of Os, but higher abundances of $\mathrm{Cr}$.

\section{5 \\ Conclusions}

Meteoritic components have been identified in about a quarter of the craters known on Earth (Table 7; Koeberl 1998). The estimates of impacting body types are dominated by chondrites ( $41 \%$ of the inferred impactors), probably because their geochemical signature is the most easily identifiable due to the relative high abundance of siderophile elements and Cr. Non-chondritic impacting bodies are often identified simply because the body was not chondritic, rather than through any firm indication that it was an achondritic or an iron body (Grieve 1991, 1997). Iron meteorites have been proposed for $34 \%$ of the impact structures, mainly on the basis of the presence of meteorite fragments, or metallic spherules, at the crater site. Conflicting identifications have been made for a number of impact structures. Both iron and chondritic projectiles have been proposed for Bosumtwi (Palme et al. 1978; Koeberl and Shirey 1993b), Zhamanshin (Palme et al. 1978; Glass et al. 1983), and Rochechouart (Wolf et al. 1980; Lambert 1982) impact structures. Many identifications based only on $\mathrm{Ni}, \mathrm{Co}$, and $\mathrm{Cr}$ studies are highly uncertain, as no PGE or isotopic data are available.

A search for siderophile anomalies at some impact structures may be unsuccessful due to a variety of reasons already mentioned above. This may include sampling problems, the impact of a differentiated projectile with little or no siderophile element enrichment with respect to terrestrial materials, or uncertainties in making corrections for indigenous siderophile elements because of 
Table 7. (cont)

\begin{tabular}{llcll}
\hline Name & Location & Diameter & Impactor & Evidence \\
\hline Chicxulub & Yucatan, Mexico & 170 & Chondrite & S, Os, Es \\
Vredefort & South Africa & 300 & Chondrite & S, Cr, Os \\
\hline
\end{tabular}

Diameters (in kilometers) from: Earth Impact Database (2002), except Morokweng (Reimold et al. 2000) *Crater field; diameter corresponds to the largest dimension of largest structure. Evidence: S, siderophile element enrichment and/or pattern; Os, Os isotopic ratio; M, meteorite fragments; MS, metallic spherules; Es, siderophile element enrichment in ejecta. References in Koeberl (1998), and later works: Kalkkop (Reimold et al. 1998), S (PGE) in Morokweng (McDonald et al. 2001) and Clearwater Lake East (McDonald 2002), $\mathrm{Cr}$ in Lappajärvi, Rochechouart and Clearwater Lake East (Shukolyukov and Lugmair 2000b), S in Boltysh (Lorenz 1999) and Mjølnir (Dypvik and Attrep 1999), M in Lappajärvi (Badjukov and Raitala 2000) and $\mathrm{Cr}$ and Os in Morokweng and Vredefort (Koeberl et al. 2001, 2002).

\section{Acknowledgements}

Frank Kyte and Iain McDonald provided constructive reviews of the manuscript; and Christian Koeberl added helpful comments and editorial advice. We thank Paul Giblin for the revision of the manuscript. This work forms part of the PhD of MJME and is also related to the main research guidelines of the Laboratory of Planetary Geology (Centro de Astrobiologia) in the framework of the IMPACT program of the ESF. The first author acknowledges a predoctoral grant (FP9820250393) from the Ministerio de Ciencia y Tecnología.

\section{References}

Anders E, Grevesse N (1989) Abundances of the elements: Meteoritic and solar. Geochimica et Cosmochimica Acta 53: 197-214

Attrep M, Orth CJ, Quintana LR, Shoemaker CS, Shoemaker EM, Taylor SR (1991) Chemical fractionation of siderophile elements in impactites from Australian meteorite craters [abs.] Lunar and Planetary Science 22: 39-40

Badjukov DD, Raitala J (2000) Schock-reworked remnants of a projectile matter in impact melts of the Lappäjarvi crater. [abs.] Lunar and Planetary Science 31: abstract no. 1591

Birck JL, Allègre CJ (1985) Isotopes produced by galactic cosmic rays in iron meteorites.

In: Isotopic Ratios in the Solar System, Cepadues-Editions, Paris, pp 21-25

Birck JL, Allègre CJ (1988) Manganese-chromium isotope systematics and development of the early solar system. Nature 331: 579-584

Bisschoff AA (1972) The dioritic rocks at the Vredefort Dome. Transactions of the Geological Society of South Africa 75: 31-45

Buchwald VF (1975) Handbook of Iron Meteorites. University of California Press, Berkeley, 1418 pp 
Cousins CA (1973) Notes on the geochemistry of the platinum group elements. Transactions of the Geological Society of South Africa 76: 77-81

Cousins CA, Vermaak CF (1976) The contribution of Southern African ore deposits to the geochemistry of the platinum group metals. Economic Geology 71: 287-305

Dypvik H, Attrep M (1999) Geochemical signals of the Late Jurasic, Mjølnir marine impact. Meteoritics and Planetary Science 34: 393-406

Earth Impact Database (2002) <http://www.unb.ca/passc/ImpactDatabase/> (Accessed: 4/October/2002)

Evans NJ, Chai CF (1997) The distribution and geochemistry of platinum-group elements as event markers in the Phanerozoic. Palaeogeography, Palaeoclimatology, Palaeoecology 132: 373-390

Evans NJ, Gregoire DC, Grieve RAF, Goodfellow WD, Veizer J (1993) Use of platinumgroup elements for impactor identification: Terrestrial impact craters and CretaceousTertiary boundary. Geochimica et Cosmochimica Acta 57: 3737-3748

Faure G (1986) Principles of Isotope Geology. 2nd Edition. J. Wiley and Sons, New York, $589 \mathrm{pp}$

Fehn U, Teng R, Elmore D, Kubik PW (1986) Isotopic composition of osmium in extraterrestrial samples determined by accelerator mass spectrometry. Nature 323: 707-710

Flores JA, Sierro FJ, Gersonde R (2002) Calcareous plankton stratigraphy around the Pliocene Eltanin asteroid impact area (SE Pacific): documentation and application for geological and paleoceanographic reconstruction. Deep Sea Research. II 49: 10111028

French BM, Nielsen RL (1990) Vredefort bronzite granophyre: chemical evidence for an origin as meteorite impact melt. Tectonophysics 171; 119-138

French BM, Orth CJ, Quintana CR (1989) Iridium in the Vredefort bronzite granophyre: impact melting and limits on a possible extraterrestrial component. In: Proceedings of the $19^{\text {th }}$ Lunar and Planetary Science Conference, Cambridge University Press and Lunar and Planetary Institute, Houston, pp 733-744

French BM, Koeberl C, Gilmour I, Shirey SB, Dons JA, Naterstad J (1997) The Gardnos impact structure, Norway: Petrology and geochemistry of target rocks and impactites. Geochimica et Cosmochimica Acta 61: 873-904

Gersonde R, Kyte FT, Bleil U, Diekmann B, Flores JA, Gohl K, Grahl G, Hagen R, Kuhn G, Sierro FJ, Völker D, Abelmann A, Bostwick JA (1997) Geological record and reconstruction of the late Pliocene impact of the Eltanin asteroid in the Southern Ocean. Nature 390: 357-363

Gladney ES, Jones EA, Nickell EJ, Roelandts I (1991) 1988 compilation of elemental concentration data for USGS DTS-1, G-1, PCC-1 and W-1. Geostandards Newsletter 15: $199-396$

Glass BP, Fredriksson K, Florensky PV (1983) Microirghizites recovered from a sediment sample from the Zhamanshin impact structure. Proceedings of the $14^{\text {th }}$ Lunar and Planetary Science Conference, Journal of Geophysical Research 88: B319-B330

Gostin VA, Keays RR, Wallace MW (1989) Iridium anomaly from the Acraman impact ejecta horizon: Impacts can produce sedimentary iridium peaks. Nature 340: 542-544

Grieve RAF (1991) Terrestrial impact - The record in the rocks. Meteoritics 26: 175-194 Grieve RAF (1997) Extraterrestrial impact events: the record in the rocks and the stratigraphic column. Palaeogeography, Palaeoclimatology, Palaeoecology 132: 5-23 
Gueddari K, La Flèche MR, Camiré G (1999) First data on platinum group elements (PGE) geochemistry of the Mont Albert peridotites (Quebec) Comptes Rendus de l'Académie des Sciences - Series IIA - Earth and Planetary Science 29: 479-486

Hartmann WK (1986) Moon origin: The impact trigger hypothesis. In: Hartmann WK, Phillips RJ Taylor GJ (eds) Origin of the Moon. Houston, Lunar and Planetary Institute, pp 579-608

Hartmann WK, Davis DT (1975) Satellite-sized planetesimals and the lunar origin. Icarus 24: 504-515

Hutcheon ID, Olsen E, Zipfel J, Wasserburg GJ (1992) Chromium isotopes in differentiated meteorites: Evidence for ${ }^{53} \mathrm{Mn}$ [abs.] Lunar and Planetary Science 23: 565-566

Jochum K (1996) Rhodium and other platinum-group elements in carbonaceous chondrites. Geochimica et Cosmochimica Acta 60: 3353-3357

Jones WB (1985) Chemical analysis of Bosumtwi crater target rocks compared with Ivory Coast tektites. Geochimica et Cosmochimica Acta 49: 2569-2576

Koeberl C (1997) Impact cratering: the mineralogical and geochemical evidence. In: Johnson KS, Campbell JA (eds) Proceedings, "The Ames structure and similar features". Oklahoma Geological Survey Circular 100, pp 30-54

Koeberl C (1998) Identification of meteoritical components in impactites. In: Grady MM, Hutchison R, McCall GJH, Rothery DA (eds) Meteorites: Flux with time and impact effects. Geological Society, London, Special Publication 140, pp 133-152

Koeberl C, Reimold WU (1995) Early Archean spherule beds in the Barberton Mountain Land, South Africa: no evidence for impact origin. Precambrian Research 74: 1-33

Koeberl C, Shirey SB (1993a) Osmium isotopes in Ivory Coast tektites: Confirmation of a meteoritic component and rhenium depletion [abs.] Lunar and Planetary Science 24: 809-810

Koeberl C, Shirey SB (1993b) Detection of a meteoritic component in Ivory Coast tektites with rhenium-osmium isotopes. Science 261: 595-598

Koeberl C, Shirey SB (1996) Re-Os isotope study of rocks from the Manson impact structure. In: Koeberl C, Anderson RR (eds) The Manson Impact Structure, Iowa: Anatomy of an Impact Crater. Geological Society of America, Special Paper 302: 311339

Koeberl C, Shirey SB (1997) Re-Os isotope systematics as a diagnostic tool for the study of impact craters and distal ejecta. Palaeogeography, Palaeoclimatology, Palaeoecology 132: $25-46$

Koeberl C, Reimold WU, Boer RH (1993) Geochemistry and mineralogy of early Archean spherule beds, Barberton Mountain Land, South Africa: evidence for origin by impacts doubtful. Earth and Planetary Science Letters 119: 441-452

Koeberl C, Sharpton VL, Schuraytz BC, Shirey SB, Blum JD, Marin LE (1994a) Evidence for a meteoritic component in impact melt rock from the Chicxulub structure. Geochimica et Cosmochimica Acta 58: 1679-1684

Koeberl C, Reimold WU, Shirey SB (1994b) Saltpan impact crater, South Africa: geochemistry of target rocks, breccias, and impact glasses, and osmium isotope systematics. Geochimica et Cosmochimica Acta 58: 2893-2910

Koeberl C, Reimold WU, Shirey SB, Le Roux FG (1994c) Kalkkop crater, Cape Province, South Africa: Confirmation of impact origin using osmium isotope systematics. Geochimica et Cosmochimica Acta 58: 1229-1234 
Koeberl C, Reimold WU, Shirey SB (1996a) A Re-Os isotope and geochemical study of the Vredefort Granophyre: clues to the origin of the Vredefort structure, South Africa. Geology 24: 913-916

Koeberl C, Reimold WU, Kracher A, Träxler B, Vormaier A, Körner W (1996b) Mineralogical, petrological, and geochemical studies of drill cores from the Manson impact structure, Iowa. In: Koeberl C, Anderson RR (eds) The Manson Impact Structure, Iowa: Anatomy of an Impact Crater. Geological Society of America, Special Paper 302, pp 145-219

Koeberl C, Armstrong RA, Reimold, WU (1997) Morokweng, South Africa: A large impact structure of Jurassic-Cretaceous boundary age. Geology 25: 731-734

Koeberl C, Reimold WU, Shirey SB (1998a) The Aouelloul crater, Mauritania: On the problem of confirming the impact origin of a small crater. Meteoritics and Planetary Science 33: 513-517

Koeberl C, Reimold WU, Blum JB, Chamberlain CP (1998b) Petrology and geochemistry of target rocks from the Bosumtwi impact structure, Ghana, and comparison with Ivory Coast tektites. Geochimica et Cosmochimica Acta 62: 2179-2196

Koeberl C, Peucker-Ehrenbrink B, Reimold WU, Shukolyukov A, Lugmair GW (2001) Comparison of $\mathrm{Os}$ and $\mathrm{Cr}$ isotopic methods for the detection of meteoritic components in impact melt rocks from the Morokweng and Vredefort impact structures, South Africa. [abs.] Catastrophic Events and Mass Extinctions: Impacts and Beyond. Abstract no. 3048

Koeberl C, Peucker-Ehrenbrink B, Reimold WU, Shukolyukov A, Lugmair GW (2002) A comparison of the osmium and chromium isotopic methods for the detection of meteoritic components in impactites: Examples from the Morokweng and Vredefort impact structures, South Africa. In: Koeberl C, MacLeod, K (eds) Catastrophic Events and Mass Extinctions: Impacts and Beyond, Geological Society of America, Special Paper 356: 607-617

Kyte FT (1998) A meteorite from the Cretaceous/Tertiary boundary. Nature 396: 237-239 Kyte FT, Brownlee DE (1985) Unmelted meteoritic debris in the Late Pliocene iridium anomaly - Evidence for the ocean impact of a nonchondritic asteroid. Geochimica et Cosmochimica Acta 49: 1095-1108

Kyte FT, Zhou Z, Wasson JT (1980) Siderophile-enriched sediments from the CretaceousTertiary boundary. Nature 288: 651-656

Kyte FT, Smit J, Wasson JT (1985) Siderophile interelement variations in the Cretaceous-

Tertiary boundary sediments from Caravaca, Spain. Earth and Planetary Science Letters 73: 183-195

Kyte FT, Zhou L, Lowe DR (1992) Noble metal abundances in an early Archean impact deposit. Geochimica et Cosmochimica Acta 56:1365-1372

Lambert P (1982) Anomalies within the system: Rochechouart target rock meteorite. In:

Silver LT, Schultz PH (eds). Geological Implications of Impacts of Large Asteroids and Comets on the Earth. Geological Society of America, Special Paper 190, pp 57-68

Lichte FE, Wilson, SM, Brooks RR, Reeves RD, Holzbecher J, Ryan DE (1986) New method for the measurement of osmium isotopes applied to a New Zealand Cretaceous/Tertiary boundary shale. Nature 322: 130-132

Lindner M, Leich DA, Russ GP, Bazan JM, Borg RJ (1989) Direct determination of the half-life of ${ }^{187}$ Re. Geochimica et Cosmochimica Acta 53: 1597-1606

Lorenz CA (1999) Trace elements geochemistry in impact melts of the Boltysh crater, Ukraine. [abs.] Lunar and Planetary Science 30: abstract no. 1597 
Luck JM, Turekian KK (1983) Osmium-187/Osmium-186 in manganese nodules and the

Cretaceous-Tertiary boundary. Science 222: 613-615

Lugmair GW, Shukolyukov A (1998) Early solar system timescales according to ${ }^{53} \mathrm{Mn}-{ }^{53} \mathrm{Cr}$ systematics. Geochimica et Cosmochimica Acta 62: 2863-2886

Mason B (1979) Meteorites. In: Data of Geochemistry, United States Geological Survey Professional Paper 440-B-1, B117-120

McDonald I (1998) The need for a common framework for collection and interpretation of data in platinum-group element geochemistry. Geostandards Newsletter 22: 85-91

McDonald I (2002) Clearwater East impact structure: A re-interpretation of the projectile type using new platinum-group element data from meteorites. Meteoritics and Planetary Science 37: 459-464

McDonald I, Hart RJ, Tredoux M (1994) Determination of the platinum-group elements in South African kimberlites by nickel sulphide fire-assay and neutron activation analysis. Analytica Chimica Acta 289: 237-247

McDonald I, Andreoli MAG, Hart RJ, Tredoux M (2001) Platinum-group elements in the Morokweng impact structure, South Africa: evidence for the impact of large ordinary chondrite projectile at the Jurassic-Cretaceous boundary. Geochimica et Cosmochimica Acta 65: 299-309

Meisel T, Krähenbühl U, Nazarov MA (1995) Combined osmium and strontium isotopic study of the Cretaceous-Tertiary boundary at Sumbar, Turkmenistan: A test for impact vs. volcanic hypothesis. Geology 23, 313-316

Meisel T, Walker RJ, Morgan JW (1996) The osmium isotopic composition of the Earth's primitive upper mantle. Nature 383: 517-520

Melosh HJ (1989) Impact Cratering: A Geologic Process. Oxford, Oxford University Press, $245 \mathrm{pp}$

Mittlefehldt DW, See TH, Hörz F (1992a) Projectile dissemination in impact melts from Meteor crater, Arizona [abs.] Lunar and Planetary Science 23, 919-920

Mittlefehldt DW, See TH, Hörz F (1992b) Dissemination and fractionation of projectile materials in the impact melts from Wabar crater, Saudi Arabia. Meteoritics 27: 361370

Montanari A, Koeberl C (2000) Impact Stratigraphy - The Italian Record. Lecture Notes in Earth Sciences, vol. 93, Springer Verlag, Heidelberg-Berlin, 364 pp

Morgan JW, Petrie KW (1979) The distribution of volatile and siderophile elements in the impact melt of East Clearwater (Quebec). Proceedings of the $10^{\text {th }}$ Lunar and Planetary Science Conference, pp 2465-2492

Morgan JW, Wandless GA (1983) Strangways Crater, Northern Territory, Australia: Siderophile element enrichment and lithophile element fractionation. Journal of Geophysical Research 88: A819-A829

Morgan JW, Higuchi H, Ganapathy R, Anders E (1975) Meteoritic material in four terrestrial meteorite craters. Proceedings of the $6^{\text {th }}$ Lunar Science Conference, pp 16091623

Morgan JW, Higuchi H, Takahashi H, Hertogen J (1978) A "chondritic" eucrite parent body; inference from trace elements. Geochimica et Cosmochimica Acta 42: 27-38

Nyquist L, Lindstrom D, Shih CY, Wiesmann H, Mittlefehldt DW, Wentworth S, Martinez $\mathrm{R}$ (1997) Mn-Cr isotopic systematics of chondrules from the Bishunpur and Chainpur meteorites [abs.] Lunar and Planetary Science 28: 1033-1034 
Palme H (1980) The meteoritic contamination of terrestrial and lunar impact melts and the problems of indigenous siderophiles in the lunar highland. Proceedings of the $11^{\text {th }}$ Lunar and Planetary Science Conference, pp 481-506

Palme H (1982) Identification of projectiles of large terrestrial impact craters and some implications for the interpretation of Ir-rich Cretaceous/Tertiary boundary layers. In: Silver LT, Schultz PH (eds) Geological Implications of Impacts of Large Asteroids and Comets on Earth. Geological Society of America Special Paper 190, pp 223-233

Palme H, Janssens MJ, Takahasi H, Anders E, Hertogen J (1978) Meteorite material at five large impact craters. Geochimica et Cosmochimica Acta 42: 313-323

Palme H, Göbel E, Grieve RAF (1979) The distribution of volatile and siderophile elements in the impact melt of East Clearwater (Quebec). Proceedings of the $10^{\text {th }}$ Lunar and Planetary Science Conference, pp 2465-2492

Palme H, Grieve RAF, Wolf R (1981) Identification of the projectile at Brent crater, and further considerations of projectile types at terrestrial craters. Geochimica et Cosmochimica Acta 45: 2417-2424

Peucker-Ehrenbrink B, Jahn B (2001) Rhenium-osmium isotope systematics and platinum group element concentrations: Loess and the upper continental crust. Geochemistry, Geophysics, Geosystems. 2: 33-59

Pierazzo E, Melosh HJ (1999) Hydrocode modeling of Chicxulub as an oblique impact event. Earth and Planetary Science Letters 165: 163-176

Pierazzo E, Melosh HJ (2000) Hydrocode modeling of oblique impacts: The fate of the projectile. Meteoritics and Planetary Science 35: 117-130

Pierazzo E, Vickery AM, Melosh HJ (1997) A reevaluation of impact melt production. Icarus 127: 408-423

Podosek FA, Ott U, Brannon JC, Neal CR, Bernatowicz TJ, Swan P, Mahan SE (1997) Thoroughly anomalous chromium in Orgueil. Meteoritics and Planetary Science 32: 617-627

Rehkämper M, Halliday AN, Alt J, Fitton JG, Zipfel J, Takazawa E (1999) Non-chondritic platinum- group element ratios in oceanic mantle lithosphere: petrogenetic signature of melt percolation? Earth and Planetary Science Letters 172: 65-81

Reimold WU, Koeberl C, Reddering, JSV (1998) The 1992 drill core from the Kalkkop impact crater, Eastern Cape Province, South Africa: stratigraphy, petrography, geochemistry and age. Journal of African Earth Earth Sciences, 26: 573-592

Reimold WU, Armstrong RA, Koeberl C (2000) New results from the deep borehole at Morokweng, North West Province, South Africa: Constraints on the size of the J/K boundary age impact structure [abs.] Lunar and Planetary Science 31: abstract no. 2074, CD-ROM

Robin E, Froget L, Jehanno C, Rocchia R (1993) Evidence for a K/T impact event in the Pacific Ocean. Nature 363: 615-617

Schmidt G (1997) Clues to the nature of the impacting bodies from platinum-group elements (rhenium and gold) in borehole samples from the Clearwater East crater (Canada) and the Boltysh impact crater (Ukraine). Meteoritics and Planetary Science 32: 761-767

Schmidt G, Pernicka E (1994) The determination of platinum group elements (PGE) in target rocks and fall-back material of the Nördlinger Ries impact crater (Germany). Geochimica et Cosmochimica Acta 58: 5083-5090

Schmidt G, Palme H, Kratz KL (1997) Highly siderophile elements (Re, Os, Ir, Ru, Rh, Pd, $\mathrm{Au}$ ) in impact melts from three European impact craters (Sääksjärvi, Mien, and 
Dellen): Clues to the nature of the impacting bodies. Geochimica et Cosmochimica Acta 61: 2977-2987

Schmidt G, Palme H, Kratz KL, Kurat G (2000) Are highly siderophile elements (PGE, Re and $\mathrm{Au}$ ) fractionated in the upper mantle of the earth? New results on peridotites from Zabargad. Chemical Geology 163: 167-188

Schnabel C, Pierazzo E, Xue S, Herzog GF, Masarik J, Cresswell RG, di Tada ML, Liu K, Fifield LK (1999) Shock melting of the Canyon Diablo Impactor: Constraints from Nickel-59 Contents and Numerical Modeling. Science 285: 85-88

Shima M, Honda M (1966) Distribution of spallation produced chromium between alloys in iron meteorites. Earth and Planetary Science Letters 1: 65-74

Shukolyukov A, Lugmair GW (1998) Isotopic evidence for the Cretaceous-Tertiary impactor and its type. Science 282: 927-929

Shukolyukov A, Lugmair GW (2000a) On the ${ }^{53} \mathrm{Mn}$ heterogeneity in the early Solar System. Space Science Reviews 92: 225-236

Shukolyukov A, Lugmair GW (2000b) Extraterrestrial matter on Earth: Evidence from the $\mathrm{Cr}$ isotopes [abs.] In: Catastrophic Events and Mass Extinctions: Impacts and Beyond, Houston, Lunar and Planetary Institute Contribution no. 1053, pp 197-198

Shukolyukov A, Lugmair GW, Koeberl C, Reimold WU (1999) Chromium in the Morokweng impact melt: isotopic evidence for extra-terrestrial component and type of the impactor [abs.]. Meteoritics and Planetary Science 34: A107-A108

Shukolyukov A, Kyte FT, Lugmair GW, Lowe DR, Byerly GR (2000) The oldest impact deposits on Earth - First confirmation of an extraterrestrial component. In: Gilmour I, Koeberl C (eds) Impacts and the early Earth, Lecture Notes in Earth Sciences, vol. 91, Springer Verlag, Berlin, pp 99-116

Smoliar MI, Walker RJ, Morgan JW (1996) Re-Os ages of group IIA, IIIA, IVA, and IVB iron meteorites. Science 271: 1099-1102

Stevenson DJ (1987) Origin of the Moon - the collision hypothesis. Annual Review of Earth and Planetary Sciences 15: 271-315

Stöckelmann D, Reimold WU (1989) The HMX mixing calculation program. Mathematical Geology. 21: 853-860

Taylor SR, McLennan SM (1985) The Continental Crust: Its Composition and Evolution. Blackwell Scientific Publications, Oxford, 312 pp

Terashima S, Imai N, Itoh S, Ando A, Mita N (1994) 1993 Compilation of analytical data for major elements in seventeen GSJ geochemical reference samples, Igneous Rock Series, Bulletin of the Geological Survey (Society) of Japan 45: 305-381

Turekian KK (1982) Potential of ${ }^{187} \mathrm{Os} /{ }^{186}$ Os as a cosmic versus terrestrial indicator in high iridium layers of sedimentary strata: In: Silver LT, Schultz PH (eds) Geological Implications of Impacts of Large Asteroids and Comets on the Earth. Geological Society of America, Special Paper 190, pp 243-249

Wallace MW, Gostin VA, Keays RR (1990) Acraman impact ejecta and host shales: Evidence for low-temperature mobilization of iridium and other platinoids. Geology 18: $132-135$

Wasson JT, Kallemeyn GW (1988) Compositions of chondrites. Philosophical Transactions of the Royal Society of London A325: 535-544

Westland AD (1981) Inorganic chemistry of the platinum-group elements. Canadian Institute of Mining and Metallurgy 23: 5-18

Wolf R, Woodrow A, Grieve RAF (1980) Meteoritic material at four Canadian impact craters. Geochimica et Cosmochimica Acta 44: 1015-1022 